\title{
SATE PADANG SUMATERA BARAT SEBAGAI GASTRONOMI UNGGULAN DI INDONESIA
}

\section{SATE PADANG WEST SUMATRA AS GASTRONOMIC FEATURED IN INDONESIA}

\author{
[1] Maulana Rahmad Sani, [2] Mirna Nur Alia, [3]Dony Riyadi \\ Prodi Manajemen Industri Katering, Fakultas Pendidikan Ilmu Pengetahuan Sosial \\ UPI \\ Email : Maulana12_9a@yahoo.com, 085794071448
}

\begin{abstract}
Sate Padang is a typical food of West Sumatra and one part traditional Indonesian food heritage. There are various types of Sate Padang circulating in different areas of West Sumatra, which each have a historical background, spice blend, and different processing. This study aimed to obtain satay as one gastronomic ethnic / ethical Padang.

This research was conducted using qualitative methods with data collection through in-depth interviews, participant observation, literature, and documentation study.

The results showed there were some kind of Sate Sate Padang include Dangung-Dangung, Peanut Sate Dangung-Dangung, Sate Padang Panjang, Sate Batusangkar, and Sate Pariaman. Each type of satay had a history, type of seasoning, processing, and marketing techniques of its own. Until now, Sate Padang as one of the specialties of West Sumatra are much in demand by domestic and foreign tourists, but not have a patent as rendang Padang. Strategic efforts are needed, especially from the government and employers Sate Padang to preserve and popularize it with patents
\end{abstract}

Keywords: Sate Padang, Food, Gastronomy, Preservation

\begin{abstract}
ABSTRAK
Sate Padang merupakan makanan khas Sumatera Barat dan menjadi salah satu bagian makanan warisan tradisional Indonesia. Terdapat beragam jenis Sate Padang yang beredar di berbagai wilayah Sumatra Barat, yang masing-masing memiliki latar belakang sejarah, racikan bumbu, serta pengolahan yang berbeda. Penelitian ini bertujuan untuk memperoleh gambaran sate sebagai salah satu gastronomi suku/ etik Padang.

Penelitian ini dilakukan menggunakan metode kualitatif dengan teknik pengumpulan data melalui wawancara mendalam, observasi partisipatif, studi literatur, dan studi dokumentasi.

Hasil penelitian menunjukkan terdapat beberapa jenis Sate Padang antara lain Sate Dangung-Dangung, Sate Kacang Dangung-Dangung, Sate Padang Panjang, Sate Batusangkar, dan Sate Pariaman. Masing-masing jenis sate tersebut memiliki sejarah,
\end{abstract}


jenis bumbu, cara pengolahan, dan teknik pemasaran tersendiri. Sampai saat ini, Sate Padang sebagai salah satu makanan khas Sumatera Barat yang banyak diminati oleh wisatawan domestik maupun mancanegara, namun belum memiliki hak paten sebagaimana rendang Padang. Diperlukan upaya-upaya strategis terutama dari pemerintah maupun pengusaha Sate Padang untuk melestarikan dan mempopulerkannya dengan hak paten.

Kata Kunci : Sate Padang, Makanan, Gastronomi, Pelestarian

\section{Pendahuluan}

Pariwisata merupakan suatu kegiatan yang dilakukan seseorang atau kelompok yang melakukan rekreasi untuk memenuhi kepuasan yang beraneka ragam. Menurut pengertiannya berdasarkan undang-undang RI No. 10 tahun 2009 tentang kepariwisataan menyebutkan bahwa pariwisata adalah :

"Berbagai macam kegiatan wisata yang didukung berbagai fasilitas serta layanan yang disediakan oleh masyarakat, pengusaha, pemerintah dan pemerintah daerah".

Menurut Suwantoro (2008: hlm, 3) pada hakikatya berpariwisata adalah suatu proses kepergian sementara dari seseorang atau lebih menuju tempat lain di luar tempat tinggalnya. Dorongan kepergiannya adalah karena berbagai kepentingan, baik karena kepentingan ekonomi, sosial, kebudayaan, politik, agama, kesehatan maupun kepentingan lain seperti karena sekedar ingin tahu, menambah pengalaman atau pun untuk belajar.

Salah satu Provinsi yang kaya akan pariwisatanya adalah Sumatera Barat. Sumatera Barat merupakan Provinsi di Indonesia yang kaya akan objek wisata, baik wisata alam, bahari maupun budaya dengan Padang sebagai ibu kotanya.

Berdasarkan data Badan Statistik Sumatera Barat, di tahun 2010-2015 jumlah wisatawan yang berkunjung ke Sumatera Barat mengalami peningkatan, yang membuat provinsi ini banyak dikunjungi wisatawan. Para wisatawan selain berekreasi menikmati tempat wisata, mereka juga berkunjung untuk mencari makanan khas yang ada di provinsi tersebut.

Banyak wisatawan domestik yang berkunjung ke Sumatera Barat ketika hari raya khususnya Iedul Fitri atau Idul Adha berwisata kuliner dan menikmati makananmakanan khas Sumatera Barat. Salah satu makanan yang banyak digemari wisatawan adalah Sate Padang. Banyak pedagang Sate Padang yang omset penjualannya naik secara signifikan, rata-rata bisa menghabiskan seribu tusuk sate atau lebih perharinya, karena banyaknya wisatawan yang ingin menikmati sate padang.

Sate Padang juga merupakan makanan khas Sumatera Barat yang mempunyai keanekaragaman jenisnya dan memiliki racikan bumbu yang berbeda pada masingmasing produsen. Sate Padang meupakan salah satu makanan warisan Indonesia yang tradisinya perlu dijaga. Sate Padang mewakili salah satu karakteristik umum hidangan tradisional Minangkabau yang merupakan bagian penting dari gastronomi Indonesia.

"Sate Padang cukup dapat merepresentasikan karakteristik umum hidangan tradisional Minangkabau. Aroma rempah yang kuat pada kuah sate Padang mencerminkan kelihaian orang Minang dalam mengolah bumbu. Meskipun pedas, 
cita rasa khas dari sate Padang pun terbukti mampu menembus batas geografis, sehingga disukai pula oleh masyarakat di daerah lain. Tak salah jika kemudian sate Padang dan kuliner khas Minangkabau lainnya dianggap sebagai salah satu penghuni kasta tertinggi dalam khasanah gastronomi Nusantara" (Indonesiakaya, 2016).

Dengan kata lain Sate Padang ini merupakan makanan khas yang penting bagi gastronomi Nusantara dan juga merupakan warisan kuliner Indonesia.

Sehubungan dengan hal tersebut maka perlu diiteliti lebih jauh ke khasan dan perkembangan kuliner Sate Padang. Hasil penelitian dapat mendukung pelestarian masakan khas daerah dan menjadi bagian penting bagi pengembangan kepariwisataan di Indonesia. Secara khusus ada tiga permasalahan yang dapat peneliti kaji dalam upaya pelestarian makanan tradisional Minang ini yaitu, (1) Bagaimana keanekaragaman sate padang di lihat berdasarkan daerah asalnya. (2) Apa yang membedakan rempah-rempah dan bumbu-bumbu sate padang pada masing-masing daerahnya. (3) Bagaimana peran Pemerintah daerah dalam melestarikan Sate Padang di Sumatera Barat.

\section{Metode Penelitian.}

Metode yang digunakan dalam penelitian ini adalah metode kualitatif, yaitu penelitian sesuatu secara mendalam. Menurut Meleong (2007 hal. 5) penelitian kualitatif merupakan penelitian yang memanfaatkan wawancara terbuka untuk menelaah dan memahami sikap, pandangan, perasaan, dan perilaku individu atau sekelompok orang. Sementara menurut Satori \& Komariah (2014 hal. 22) penelitian kualitatif merupakan penelitian yang menekankan pada quality atau hal yang terpenting dari sifat suatu barang/jasa. Hal terpenting dari suatu barang atau jasa berupa kejadian/fenomena/gejala social yang mempunyai makna dibalik kejadian tersebut yang dapat dijadikan pelajaran yang berharga bagi suatu pengembangan konsep teori.

Dalam penelitian ini peneliti yang akan menjadi instrumen utama didalam penelitian ini. Menurut Meleong (2007, hal. 163) peranan manusia sebagai instrumen penelitian merupakan ciri khas penelitian kualitatif yang tidak dapat dipisahkan dari pengamatan berpraserta, namun peranan penelitilah yang menentukan skenarionya. Kedua hal tersebut diuraikan dalam bagian ini secara berturut-turut. Peneliti dalam hal ini melakukan wawancara kepada beberapa narasumber pedagang Sate Padang dan Dinas Pariwisata daerah Provinsi Sumatera Barat untuk memperoleh hasil dari penelitian yang dilakukan. Selain wawancara mendalam, peneliti juga melakukan observasi dalam proses pembuatan sate, serta melakukan studi dokumentasi.

Peneliti dalam hal ini ingin mengetahui keanekaragaman Sate Padang berdasarkan daerah asalnya, mengetahui perbedaan bumbu-bumbu dan rempahrempah pada masing-masing daerahnya dan upaya pemerintah dalam melestarlamikan Sate Padang.

\section{Kajian Teoritis}

Menurut Taqwani (2012, hal. 55) gastronomi merupakan studi mengenai hubungan antara budaya dan makanan, di mana gastronomi mempelajari berbagai komponen budaya dengan makanan sebagai pusatnya (seni kuliner) yang berbungan 
dengan budaya. Gastronomi terbentuk karena gastronomi merupakan produk budidaya yang terjadi pada kegiatan pertanian sehingga menghasilkan warna, aroma, dan rasa dari suatu makanan yang dapat ditelusuri asal-usulnya dari lingkungan tempat bahan baku yang dihasilkannya.

Sedangkan Menurut Santich B (2004) dalam artikel Indra Ketaren, Antara Gastronomi dan Kuliner mengemukakan bahwa Gastronomi adalah panduan mengenai berbagai cara yang melibatkan setiap hal tentang makanan dan minuman. Kajiannya sangat interdisipliner yang berkaitan dengan refleksi dari sebuah sejarah, dampak budaya dan suasana lingkungan mengenai "bagaimana (how), di mana (where), kapan (when) dan mengapa (why)" makanan dan minuman menjadi penting bagi masyarakat dan industri jasa makanan.

Menurut Astawan (2013, hal.1) dalam bukunya "jangan takut makan enak sehat dengan makanan tradisional", sudah menjadi kewajiban kita bersama untuk memelihara dan mencintai makanan tradisional Indonesia dan menjadikannya sebagai salah satu unsur budaya dan bangsa. Jangan sampai makanan leluhur dan nenek moyang kita dipatenkan oleh bangsa-bangsa lain, seperti yang terjadi pada tempe. Di beberapa negara terbukti bahwa dengan pengembangan makanan tradisional dapat memberikan andil yang cukup besar bagi pengembangan wisata dan peningkatan didalam memperoleh devisa

Menurut Alamsyah (2008, hal.21-23) keunggulan kuliner tradisional dapat dijadikan sebagai sebuah panduan berbisnis yang sangat penting untuk mengenali kebiasaan konsumen terhadap pola makan yang ditandai dengan ciri khusus, bahwa orang Indonesia menyukai masakan dengan hal sebagai berikut :

1. Rasa gurih, merupakan suatu unsur utama saat memilih masakan. Rasa gurih ini berasal dari kandungan lemak, protein atau garam yang ada di dalam makanan tersebut.

2. Berbumbu (spicy), jenis masakan Indonesia rata-rata sarat dengan bumbu, bahkan ada yang sampai menghilangkan rasa asli dari bahan baku tersebut. Perpaduan rasa yang dihasilkan antara bahan baku dan bumbu akan menghasilkan flavour yang unik yang disukai semua orang. Salah satunya adalah masakan padang, adalah masakan yang sarat dengan masakan bumbu yang bisa diterima di hampir seluruh Indonesia. Karena Indonesia dikenal sebagai negara dengan penghasil bumbu sejak dari zaman penjajahan Belanda.

3. Rasa Sensasional, rata-rata orang menyukai rasa yang sensasional dan membangkitkan selera makan semisal ras pedas, asin, asam atau manis. Salah satu contohnya adanya unsur cabe di setiap masakan atau di meja makan disediakan sambel. Sambel ini berfungsi sebagai pelengkap dari masakan dan memiliki peran yang penting. Karena tanpa adanya sambel masakan jadi tidak terasa dan tidak memiliki arti apapun. Boleh jadi dapat dikatakan semua masakan disajikan dengan sambel.

4. Tanpa aturan baku (fleksible), artinya kuliner tradisional masih kurang memegang aturan baku di dalam pola makan seperti halnya layaknya kuliner Internasional lainnya. Boleh jadi didalam masakan tradisional tidak mengenal makanan pembuka seperti salad, makanan penutup seperti puding dan makanan utama (main course) yaitu makanan utama yang disajikan berupa nasi dan lauk. 
Adapun dibeberapa kuliner luar negeri kita bisa mengenal jenis makanan untuk sarapan, makan siang untuk lunch dan makan malam untuk dinner. Namun untuk masakan tradisional bisa berfungsi sebagai apapun. Contoh, pecel dilihat dari sudut komposisi adalah salad atau makanan pembuka, tapi justru pecel ada yang dijadikan sebagai lauk yang menemani nasi dan lontong. Namun ada di beberapa daerah lainnya menganggap pecel adalah makanan sarapan, tapi di lain tempat pecel dihidangkan malam hari.

5. Unik, artinya masakan tradisional dapat memperlihatkan keunggulan daerah asal atau mewakili simbol dari daerah atau mewakili dari simbol daerah simbol daerah itu sendiri. Pada setiap daerah meski terkadang ada kesamaan namun selalu ada memiliki perbedaan. Perbedaan ini bisa dari cara makan, komposisi bumbu, fungsi masakan atau cara hidang. Sehingga masakan tradisional ini dapat dikatakan tidak terlepas dari indentitas daerah asal serta keaslian masakan yang menjadi nilai tambah yang akan selalu diperhitungkan disaat membuka usaha masakan tradisional. Semisal didalam membuka usaha warung soto surabaya, menjadi suatu daya tarik tersendiri karena soto memiliki ciri khas khusus dan begitupun dengan jenis masakan lainnya yang menyertakan nama daerah asal.

Menurut Suparni \& Wulandari (2012, hal. 6-7) Bumbu adalah bahan yang berasal dari alam, tumbuh-tumbuhan, atau sumber hewani yang berguna untuk memberikan rasa khas pada masakan dan digunakan dalam keadaan kering atau segar. Sedangkan rempah -rempah adalah bahan-bahan yang berasal dari tumbuhan, berfungsi untuk memberikan aroma dan cita rasa khusus pada masakan. Biasanya rempah-rempah digunakan dalam keadaan kering.

Fungsi dari bumbu dan rempah adalah :

1. Memberi rasa pada makanan.

2. Memberi warna pada makanan.

3. Meningkatkan rasa dan aroma.

4. Membantu pencernaan makanan.

Berdasarkan asalnya bumbu dan rempah dapat dikelompokkan menjadi enam kelompok, yaitu :

1. Bumbu yang berasal dari buah dan biji. Misalnya kemiri, cabe, peprika, belimbing, wuluh, kapulaga, lada, dan lain-lain.

2. Bumbu yang berasal dari bunga, misalnya cengkeh, caper, saffron, dan lainlain.

3. Bumbu yang berasal dari daun, misalnya daun salam, daun jeruk purut, dan lain-lain.

4. Bumbu yang berasal dari akar, misalnya kunyit, jahe, kencur, lengkuas, dan lain-lain.

5. Bumbu yang berasal dari umbi lapis, misalnyabawang merah, bawang putih, bawang bombay, daun bawang prei, dan lain-lain.

Menurut Menurut Rachman (2012, hal. 31) mempunyai yaitu melestarikan mengawetkan daya dukung, mutu, fungsi, dan kemampuan lingkungan secara seimbang yang dikutip dari (MIPL, 2010; Anugrah, 2008; Wahyudi dan DYP Sugiharto (ed), 2010). Di sisi lain menurut Widyawati \& Syahbana (2013, hal. 305306) pelestarian secara umum dapat didefinisikan sebagai suatu usaha atau kegiatan 
untuk merawat, melindungi dan mengembangkan objek pelestarian yang memiliki nilai guna untuk dilestarikan.

Menurut Wardhana \& Zaini (2015, hal. 142) pengertian ikon yang dikutip Mikke Susanto (2012: hal.189) merupakan sebuah tanda yang memiliki kemiripan rupa antara tanda dan hal yang diwakilinya. Dalam sistem semiotika pierce, ikon adalah sebuah tanda yang dapat berfungsi dengan cara memiripkan objeknya atau membuat sama. Sedangkan menurut Marzuqi, Alif Fianto, \& Hidayat (2015, hal. 3) ikon adalah tanda yang mewakili sumber acuan melalui sebuah bentuk replikasi, simulasi, imitasi, atau persamaan.

Menurut undang-undang RI No. 10 tahun 2009 tentang kepariwisataan menyebutkan bahwa pariwisata adalah :

"Berbagai macam kegiatan wisata yang didukung berbagai fasilitas serta layanan yang disediakan oleh masyarakat, pengusaha, pemerintah dan pemerintah daerah".

Menurut pendapat Pitana dan Gayatri (2007, hal. 109) pariwisata merupakan suatu kegiatan yang secara langsung menyentuh dan melibatkan masyarakat, sehingga membawa berbagai dampak terhadap masyarakat setempat. Bahkan pariwisata dikatakan mempunyai energi dobrak yang luar biasa, yang mampu membuat masyarakat setempat mengalami metamorfose dalam berbagai aspeknya.

\section{Hasil Penelitian dan Pembahasan}

Sate Padang memiliki keanekaragaman jenis dan yang terkenal antara lain: Sate Dangung-Dangung, Sate Kacang Dangung-Dangung, Sate Padang Panjang, Sate Batusangkar dan Sate Pariaman. Masing-masing sate memiliki sejarah, tempat dan cita rasa makanan khas yang berbeda. Sate Padang juga berkaitan dengan budaya dan lingkungan karena dengan adanya Sate Padang berdampak pada naiknya perekonomian masyarakat Minang yang menjual Sate Padang. Banyak pedagang Sate Padang juga yang bisa mendagangkan satenya di hari Lebaran dengan jumlah banyak dan mendapatkan untung berlebih. Dampak lainnya dari Sate Padang ini juga banyak orang yang pulang ke kampung halaman untuk mencicipi Sate Padang karena ada yang beranggapan jika tidak makan Sate Padang maka tidak pulang ke kampung halaman. Keadaan suasana lingkungan lainnya dari Sate Padang adalah sate dijadikan sarapan pagi bagi masyarakat Minang yang pengungjungnya dari anak sekolah

Sate Padang memiliki bumbu-bumbu dan rempah-rempah yang berbeda pada masing-masing satenya yang memiliki ciri khas tersendiri pada satenya.

Sate Dangung-Dangung memiliki keunikan kuah khas yang berwarna kuning dengan warna kuning yang didapat dari kunyit dan cita rasa khas Dangung-Dangung dengan daging sapi yang digunakan pada Sate Dangung-Dangung ini terdiri dari bagian lidah, jantung, pipi, dada, punggung dan sekitar bagian kepala sapi. Sate Dangung-Dangung ini juga banyak dinikmati di hari Lebaran karena banyaknya masyarakat Minang yang berkunjung ke kampung halaman untuk menikmati Sate Padang yang dapat menghasilkan devisa bagi daerah Dangung-Dangung. Sate Kacang Dangung-Dangung memiliki keunikan kuah khas yang berwarna kecokelatan 
karena memakai kacang tanah yang ditumbuk sebagai kuahnya dengan olahan daging sapi yang digunakan pada Sate Kacang Dangung-Dangung ini menggunakan daging ass dalam. Proses memasak dagingnya juga tidak melalui proses ditumis terlebih dahulu namun daging di bumbui dan langsung dibakar yang menjadi keunikan dari Sate Kacang Dangung-Dangung ini yang tentunya cita rasanya berbeda dengan Sate Dangung-Dangung. Pada hari lebaran juga Sate Kacang Dangung-Dangung banyak dinikmati oleh pengungjungnya yang sama dapat menghasilkan devisa bagi daerah Dangung-Dangung. Sate Padang Panjang memiliki kuah khas yang berwarna kuning yang sama halnya dengan Sate Dangung-Dangung. Namun racikan bumbu dan rempahnya yang membuatnya berbeda dengan Sate Dangung-Dangung sehingga memiliki keunikan tersendiri di setiap satenya. Pengolahan daging sapinya sendiri menggunakan daging iga dan dada. Sama halnya seperti daerah Dangung-Dangung, di hari lebaran sate ini bisa menghasilkan devisa daerah Padang Panjang. Sate Batusangkar juga memiliki kenikan kuah khas berwarna kuning kecoklatan. Warna kuning berasal dari pewarna makanan sedangkan warna cokelat didapatkan dari kacang tanah yang digilingdengan olahan daging sapi yang didapatkan pada Sate Batusangkar ini menggunakan daging paha usus dan babat. Sate Batusangkar ini juga dapat menghasilkan devisa bagi Sumatera Barat karena banyak wisatawan yang ingin menikmati Sate Padang. Sate Pariaman mempunyai keunikan kuah khas yang berwarna merah. Warna merah berasal dari pewarna makanan dengan olahan daging sapi yang digunakan pada jenis sate ini menggunakan daging paha, usus dan jantung. Sate Pariaman ini juga dapat menghasilkan devisa bagi Sumatera Barat karena banyak wisatawan yang ingin menikmati Sate Padang jenis ini.

Pada dasarnya bumbu dan rempah memiliki arti yang hampir sama, tetapi berbeda pada asal dari kondisi bahan pada saat penggunaannya.

Sate Padang pada dasarnya secara spesifiknya memiliki bumbu-bumbu dan rempah-rempah yang sama pada masing-masing daerahnya yang berasal dari Sumatera Barat. Namun pada masing-masing Sate Padang yang terdiri dari Sate Dangung-Dangung, Sate Kacang Dangung-Dangung, Sate Padang Panjang, Sate Batusangkar, Sate Pariaman juga memiliki tambahan bumbu dan rempah serta racikan yang berbeda pada masing-masing daerahnya.

Peran upaya Pemerintah daerah dalam melestarikan Sate Padang ini dengan cara memberikan informasi kepada wisatawan domestik dan mancanegara dengan memberikan spot kuliner yang ada. Kemudian menfasilitasi pedagang-pedagang Sate Padang di dalam memperkenalkan dan mengembangkan Sate Padang. Agar mutu, fungsi tetap utuh, serta menjadikan objek Sate Padang sebagai salah makanan tradisional Sumatera Barat yang secara gastronomi perlu dijaga dan dilestarikan karena memiliki sejarah, komponen budaya dan juga lingkungan yang mempengaruhi asal mulanya sate ini.

Untuk menjadikan Sate Padang sebagai ikon dan mematenkannya belum bisa terlaksanakan oleh Pemerintah Dinas Pariwisata daerah karena banyak pertimbangan izin-izin yang perlu dilakukan yang juga Sate Padang ini yang memiliki keanekaragaman macam jenisnya dan banyaknya pedagang Sate Padang yang belum terbuka dengan usahanya mulai dari resepnya atau cara proses pembuatan Sate Padang yang membuat untuk menjadikan hak paten untuk Sate Padang ini lebih sulit 
dilakukan. Namun harus sudah menjadi tugas Pemerintah Dinas Pariwisata untuk melakukan suatu gebrakan agar Sate Padang menjadi komponen penting dari gastronomi Indonesia.

Sate Padang dalam hal ini juga merupakan salah satu tempat wisata kuliner yang berkaitan dengan masyarakat, pengusaha, dan pemerintah dan merupakan bagian dari gastronomi Indonesia. Sebab Sate padang ini juga merupakan sebuah (seni kuliner) yang berbungan dengan budaya yang menghasilkan warna, aroma, dan rasa dari suatu makanan yang berkaitan dengan asal-usulnya dari lingkungan tempat bahan baku yang dihasilkannya. Hal demikian yang membuat Sate Padang ini perlu dijaga dan dilestarikan

Sate Padang merupakan tempat wisata kuliner yang mempunyai daya tarik tersendiri yang dapat mendombrak masyarakat daerah, luar daerah, pejabat daerah, Bupati, sampai Presiden datang untuk menikmati Sate Padang di Sumatera Barat. Sebab hal tersebut itu juga yang membuat Sate Padang ini perlu dijadikan sebuah ikon dan membuat hak paten tersendiri seperti halnya rendang.

\section{Simpulan dan Saran}

Berdasarkan hasil wawancara dan observasi yang dilakukan oleh peneliti dapat disimpulkan bahwa Sate Padang ini memiliki keanekaragaman jenisnya dan juga memiliki racikan yang berbeda di setiap satenya serta perlu pengembangan lebih lanjut di dalam melestarikannya agar tetap menjadi hidangan tradisional Minangkabau yang penting dari gastronomi Indonesia dan kuliner Nusantara.

Dengan saran yang perlu dilakukan oleh peneliti mengenai pelestarian Sate Padang ini antara lain:

1. Adanya buku referensi tentang Sate Padang dalam rangka memperkenalkan dan mempromosikan Sate Padang kedalam dunia pariwisata baik di tingkat daerah, Nasional maupun Internasional.

2. Adanya penggunaan pewarna alami pada Sate Padang karena pada setiap rempah-rempah dan bumbu-bumbu memiliki manfaat bagi kesehatan.

3. Penggunaan rempah-rempah dan bumbu-bumbu yang ada pada Sate Padang lebih banyak digunakan agar menghindari penggunaan penyedap rasa pada satenya

4. Adanya peran pemerintah dalam hal ini harus berperan aktif dalam menaikkan popularitas dari Sate Padang agar menjadi ikon kuliner kedua bagi Sumatera Barat selain dari pada rendang.

5. Adanya peran pemerintah dalam hal ini membuatkan hak paten kepada macam-macam Sate Padang agar mempunyai hak paten pada masing-masing satenya yang didukung dengan peran pedagang Sate Padang, yang dimana dalam hal ini harus memiliki sifat keterbukaan terhadap usaha Sate Padang yang dimilikinya agar mempermudah pembuatan hak paten.

\section{Daftar Pustaka}

\section{Buku}

Alamsyah, Yuyun. (2008).Bisnis

Media Komputindo
Kuliner Tradisional. Jakarta :

PT Elex 
Astawan, Made. (2013). Jangan Takut Makan Enak Sehat Dengan Makanan Tradisional.Jakarta : 2013

Meleong, J. L. (2007). Metodologi Penelitian Kualitatif. Bandung: PT Remaja Rosdakarya Offset.

Pitana, I. G., \& Gayatri, P. G. (2008). Sosiologi Pariwisata. Yogyakarta: ANDI OFFSET.

Republik Indonesia. (2009). Undang- $\quad$ Undang RI No. 10 tahun 2009 tentang Kepariwisataan. Sekretariat Negara. Jakarta

Satori, D., \& Komariah, A. (2014). Metodologi Penelitian Kualitatif. Bandung: Penerbit Alfabeta.

Suparni, I., \& Wulandari, A. (2012). Herbal Nusantara 1001 Ramuan Tradisional Asli Indonesia. Yogyakarta: ANDI OFFSET.

Suwantoro, G. (2008). Dasar-Dasar Pariwisata. Yogyakarta: $\quad$ ANDI

Jurnal

Marzuqi, A., Alif Fianto, Y. A., \& Hidayat, W. (2015). Vol.4. No.1 Penciptaan Motif Batik Sebagai Ikon. Jurnal Desain Komunikasi Visual, 3.

Rachman, M. (2012).Vol.1 No.1 Konservasi Nilai Dan Warisan Budaya. Indonesian Journal of Conservation, 31.

Taqwani, D. M. (2012). a- research.upi.edu. Analisis Kebudayaan Gastronomi

Dan Tindak Tutur Dalam Kajian Pragmatik Pada Film Ratatouille, 55

Wardhana, K. A., \& Zaini, I. (2015). Volume 3. Nomor 3. PENERAPAN GAMBAR ILUSTRASI BERBENTUK Ikon Kota Surabaya Untuk Meredesain Majalah Sekolah Di SMP Negeri 47 Surabaya. Jurnal Pendidikan Seni Rupa, 142.

\section{Website}

Budaya.Rimanews. (2016, Mei 17). Dipetik Mei 17, 2016, dari http://budaya.rimanews.com/:

http://budaya.rimanews.com/read/20140519/151846/Indra-Ketaren-AntaraGastronomi-dan-Kuliner

Indonesiakaya. (2016). Dipetik April 20, 2016, dari www.indonesiakaya.com: http://www.indonesiakaya.com/kanal/detail/sate-padang-si-pedas-gurih-yangmenggoyang-lidah

Sumbar.bps. (2016). Dipetik Februari 20, 2016, dari sumbar.bps.go.id:

http://sumbar.bps.go.id/ 